\title{
Detection of activity similar to that of early pregnancy factor after mating sows with a vasectomized boar
}

\author{
E. Koch* and F. Ellendorff
}

Institut für Tierzucht und Tierverhalten (FAL), Mariensee, 3057 Neustadt 1, Federal Republic of Germany

\begin{abstract}
Summary. Incubation of normal pig lymphocytes in serum samples collected from 10 sows immediately before, and at daily intervals after mating with a vasectomized boar significantly elevated the rosette inhibition titre (RIT) of a standard antilymphocyte serum in 6 animals on the first but not on the 2 nd and 3rd day after copulation. Infusion of seminal plasma without mating into 5 sows induced an obvious, but not statistically significant, transient rise of titres in 3 pigs. Neither sodium chloride infusion $(N=5)$, nor sham copulation with diverted penis $(\mathrm{N}=5)$ influenced serum RITs. Porcine seminal plasma showed an inherent rosette-inhibiting property. A depression of rosette formation was evident in a concentration-dependent fashion up to a dilution of 1 in 320. Similarly, preincubation of lymphocytes in serial dilutions of seminal plasma in a non-pregnancy serum sample led to an amplification of the rosette inhibiting capacity of the antilymphocyte serum. Non-specific activation of the eggs to release a signal which induces the production of early pregnancy factor (EPF) or the resorption of seminal plasma components into the blood circulation are considered as possible explanations for the EPF-like activity after mating with a vasectomized boar.
\end{abstract}

\section{Introduction}

The term "early pregnancy factor (EPF)" describes an activity found for lymphocytes and in sera of a number of mammalian species (see Morton, Rolfe \& Cavanagh, 1982a). This activity is demonstrated by the rosette inhibition test, in which it partly replaces the antilymphocyte serum needed to inhibit the formation of spontaneous rosettes between lymphocytes and heterologous erythrocytes (Morton, Tinneberg, Rolfe, Wolf \& Mettler, 1982b).

The detection of this phenomenon within hours after copulation, e.g. as early as $4 \mathrm{~h}$ after mating in mice (Morton, Hegh \& Clunie, 1976), is thought to be specific for fertilization and the continuous presence of a viable conceptus (Morton et al., 1982a). This contention is based on observations that neither the presence of spermatozoa in the genital tract of sterilized female mice (Morton $e t$ al., 1976), sheep (Morton, Nancarrow, Scaramuzzi, Evison \& Clunie, 1979) and women (Smart, Roberts, Fraser, Cripps \& Clancy, 1982), nor mating of intact female mice with a vasectomized male (Morton et al., 1976) increased the rosette inhibition titre (RIT) of a standard antilymphocyte serum.

In pregnant sheep, on the other hand, the raised serum inhibition titres fell to the nonpregnancy range within $48 \mathrm{~h}$ after interruption of pregnancy by induction of luteolysis or surgical removal of embryos (Nancarrow, Evison, Scaramuzzi \& Turnbull, 1979). In-vitro experiments with different mouse organs have suggested that the production of one entity of the EPF-complex can only be initiated from oestrous or dioestrous ovaries in the presence of fertilized ova and in cooperation with dioestrous pituitaries (Morton et al., 1980). Therefore, a signal of the fertilized 
ovum, termed ovum factor, has been proposed which subsequently stimulates the production of EPF (Cavanagh, Morton, Rolfe \& Gidley-Baird, 1982).

Although pig spermatozoa may achieve the ability to fertilize ova within $3 \mathrm{~h}$ after copulation (Hunter \& Dziuk, 1968), the presumed pregnancy-specific detection of EPF activity in the peripheral blood within 4-6 h after mating (Koch, Morton, Morton \& Ellendorff, 1982) has raised some doubts. To test whether EPF production in the pig is stimulated solely by fertilization or may also be induced by a sterile mating, we determined rosette inhibition titres after the incubation of lymphocytes in serum samples taken from oestrous sows before and after mating with a vasectomized boar. The effects of sham copulation with a diverted penis as well as the intracervical infusion of seminal plasma or saline were also tested and the influence of seminal plasma on the formation of spontaneous rosettes and its ability to modify the rosette inhibitory activity of a nonpregnancy serum were investigated.

\section{Materials and Methods}

Animals and experiments. For the different experiments 25 German Landrace gilts and sows were randomly selected out of the Institute's stock. They were kept under daylight conditions at the Institute's farm and provided twice daily with a pelleted pig chow and water. The animals were tested daily for the onset of oestrus. As soon as they showed receptivity determined by the standing reflex, the pigs were divided into four groups: in Group 1, 10 animals were mated once with a vasectomized boar; in Group 2, 5 animals were sham-copulated without introduction of the diverted penis; in Group 3, 5 animals received a single intracervical infusion of $150 \mathrm{ml}$ seminal plasma $\left(37^{\circ} \mathrm{C}\right)$; and in Group 4, 5 animals were intracervically infused with $150 \mathrm{ml} 0.9 \%(\mathrm{w} / \mathrm{v})$ sodium chloride $(\mathrm{NaCl})\left(37^{\circ} \mathrm{C}\right)$. In accordance with the $\mathrm{pH}$ of two seminal plasma samples ( $\mathrm{pH} 7.98$ and 8.03 ) the $\mathrm{pH}$ of the $\mathrm{NaCl}$ solution was adjusted to 8.0 by the addition of sodium bicarbonate.

Blood samples were collected from these pigs immediately before and 24,48 and $72 \mathrm{~h}$ after mating or infusion. After standing for about $1 \mathrm{~h}$ at room temperature serum was removed by centrifugation $(20 \mathrm{~min}, 1000 \mathrm{~g})$ and then stored at $-25^{\circ} \mathrm{C}$ until used.

For matings, for simulated copulations with diverted penis and for the collection of seminal plasma, two vasectomized German Landrace boars were utilized. Both animals were sterilized at 6.5 months of age and a body weight of about $110 \mathrm{~kg}$ as described by Smidt (1965). Absence of spermatozoa in a complete ejaculate was tested microscopically before the experiment (beginning 4 weeks after surgery). Seminal plasma (without bulbourethral components) for the intracervical infusion experiments was always collected immediately before use. For in-vitro tests seminal plasma was stored in $0.3 \mathrm{ml}$ volumes at $-25^{\circ} \mathrm{C}$ and thawed only once before use.

Preincubation of lymphocytes. Lymphocytes were isolated from heparinized blood by gradient centrifugation following collection from a jugular vein catheter in castrated male pigs. The lymphocytes were washed twice $(5 \mathrm{~min}, 200 \mathrm{~g}$ ) in Hanks' balanced salt solution without calcium and magnesium (HBSS; Serva, Heidelberg, F.R.G.), and finally made up to a concentration of 15000 cells/ $/ \mathrm{l}$. Volumes of this suspension $(1.2 \mathrm{ml})$ were centrifuged, the supernatants were removed and the cells incubated for $30 \mathrm{~min}$ at $37^{\circ} \mathrm{C}$ in one of the following preparations:

(1) $0.2 \mathrm{ml}$ diluted serum ( 1 in 2 with HBSS) from the above pigs. Before incubation the serum was inactivated $\left(30 \mathrm{~min}, 56^{\circ} \mathrm{C}\right)$ and dialysed against phosphate-buffered saline (PBS) overnight (about $16 \mathrm{~h}$ ) at $4^{\circ} \mathrm{C}$;

(2) $0.2 \mathrm{ml}$ seminal plasma, undiluted and serially double-diluted with HBSS over a range of 1 in 5 to 1 in 5120 ;

(3) $0.2 \mathrm{ml}$ diluted seminal plasma: the seminal plasma was diluted at the ratio of $1 / 80,1 / 160$, $1 / 320$ and $1 / 640$ with serum of a non-pregnant sow taken on the first day after weaning the piglets (about 5 weeks after birth). Before preincubation of lymphocytes these dilutions were incubated for 
$30 \mathrm{~min}$ at $37^{\circ} \mathrm{C}$, subsequently inactivated $\left(30 \mathrm{~min}, 56^{\circ} \mathrm{C}\right)$ and dialysed against PBS overnight; (4) $0.2 \mathrm{ml}$ HBSS alone.

After the incubation period the lymphocytes were washed twice and resuspended in $1.2 \mathrm{ml} \mathrm{HBSS}$.

Test for EPF activity. The rosette inhibition test was applied using a single antilymphocyte serum for all tests. The preparation of the materials and the methodology have been described in detail (Morton et al., 1982b; Koch \& Ellendorff, 1985). In brief, a mixture of preincubated lymphocytes $(100 \mu \mathrm{l} ; 15000$ cells $/ \mu \mathrm{l})$, a series of 10 different antilymphocyte serum dilutions $(250 \mu \mathrm{l}$; 4-fold diluted from $1 / 1000$ to $1 / 256 \times 10^{6}$ ) and guinea-pig serum (diluted 1 in 5 with HBSS; $50 \mu$ ) was incubated for $90 \mathrm{~min}$ at $37^{\circ} \mathrm{C}$. Formation of spontaneous rosettes was achieved by the addition of $100 \mu \mathrm{l}$ suspension of sheep RBCs $\left(10^{5}\right.$ cells $\left./ \mu \mathrm{l}\right)$ and centrifugation for $5 \mathrm{~min}$ at $200 \mathrm{~g}$. Subsequently the mixture was resuspended by gentle rotation on a wheel ( $5 \mathrm{~min}, 5$ r.p.m.). The rosette inhibition titre (RIT) was defined as the highest dilution of antilymphocyte serum which caused, compared to two internal controls without added serum, a reduction of the rosette number by at least $25 \%$. The titre of this dilution was expressed as the logarithm to base 2 . An RIT of at least 14 was ascertained from previous experiments to indicate the presence of EPF activity (Koch \& Ellendorff, 1985).

Formation of spontaneous rosettes. A lymphocyte suspension $(100 \mu \mathrm{l} ; 15000$ cells/ $\mu \mathrm{l})$, preincubated in undiluted or HBSS-diluted seminal plasma, was incubated for a further $90 \mathrm{~min}$ at $37^{\circ} \mathrm{C}$ with $250 \mu \mathrm{l} \mathrm{HBSS}$ and $50 \mu \mathrm{l}$ of diluted guinea-pig serum. Rosettes were formed by the addition of $100 \mu \mathrm{l}$ sheep RBC suspension $\left(10^{5} \mathrm{cells} / \mu \mathrm{l}\right)$ as described above. Duplicate aliquants of each dilution were spread on a haemocytometer and the number of rosettes calculated as a percentage of the total lymphocyte number. Inhibition of rosette formation was evaluated by comparison with the rosette number after preincubation of lymphocytes in HBSS alone.

Statistical analysis. The mean \pm s.e.m. is indicated in the text and the figures. Differences were tested by a Mann-Whitney U-test, if not normally distributed, or by a Student's $t$ test, and considered to be significant at $P<0 \cdot 05$.

\section{Results}

\section{Effect of mating with a vasectomized boar}

By $24 \mathrm{~h}$ after mating with a vasectomized boar, EPF activity was detected in 6 of 9 tested animals. The mean titre was significantly $(P<0.01)$ increased from $10.8 \pm 0.33$ (range 10-12) before copulation to $16.0 \pm 1 \cdot 25$ (range 10-22) after copulation. In one pig, no serum sample was available on the first day after copulation, but on the 2 nd and the 3 rd day after mating titres of 16 and 14 respectively, were obtained. Serum samples of the remaining animals yielded inhibition titres within the non-pregnancy range (RIT 10-12) on both days (Text-fig. 1).

\section{Effect of sham copulation}

Before a simulated mating without introduction of the diverted penis, EPF-positive titres were detected in 2 (RIT 14 in each case) out of 5 animals. Serum of a third pig caused enhanced rosette inhibition (RIT 16) on the first day after sham copulation, whereas one animal, whose serum had already induced an increased titre before mating, again had a titre of $1448 \mathrm{~h}$ later. Statistically significant effects of the sham copulation were not demonstrable (Text-fig. 1).

\section{Effect of seminal plasma infusion}

Before intracervical infusion of seminal plasma a mean inhibition titre of $10.4 \pm 0.40$ (range $10-12, \mathrm{~N}=5$ ) was estimated. By $24 \mathrm{~h}$ after application EPF activity was found in serum of 3 pigs (RIT 14, 20 and 24). The increase of the mean titre (15.6 $\pm 2 \cdot 79)$ was not statistically significant 


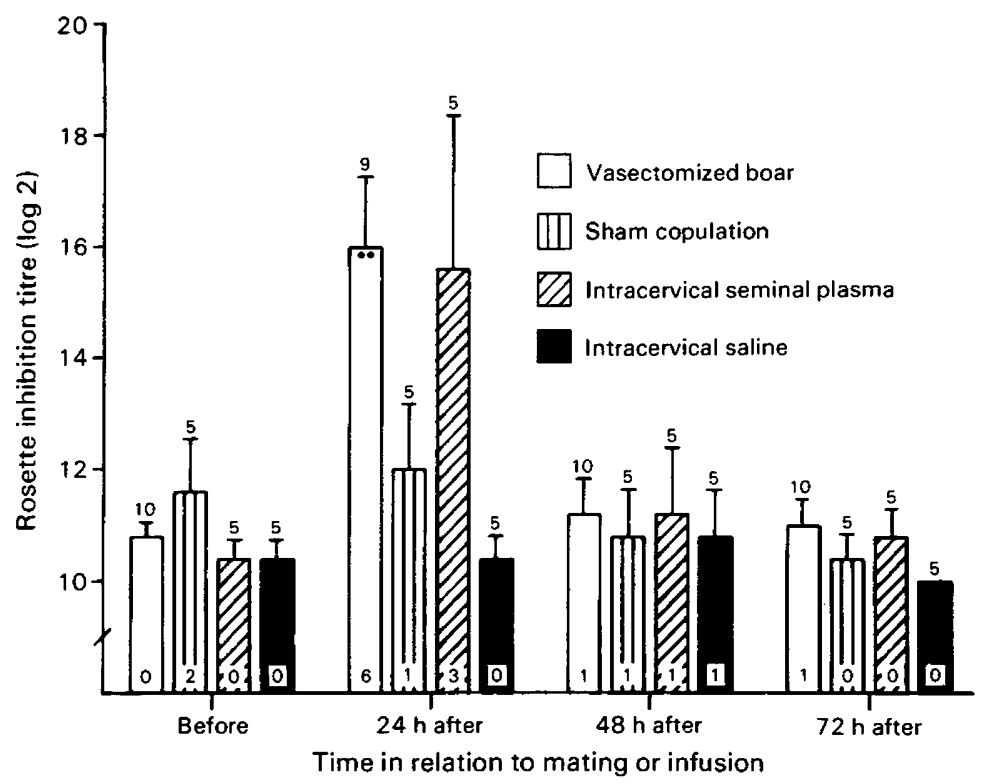

Text-fig. 1. Mean RIT \pm s.e.m. with serum samples taken from pigs immediately before and at various times after mating with a vasectomized boar, sham copulation, intracervical infusion of $150 \mathrm{ml}$ seminal plasma or intracervical infusion of $150 \mathrm{ml}$ saline. Number of pigs tested are given at the top of the bars. Number of animals with EPF-positive serum titres (RIT > 12) are indicated within the bars.

** $P<0.01$ compared to values before treatment.

$(P>0.07)$. On the 2 nd day after treatment one animal still showed an EPF-positive titre (RIT 16 vs RIT 20 on 1st day after infusion). By $72 \mathrm{~h}$ after seminal plasma infusion, none of the serum samples taken induced an elevated titre (Text-fig. 1).

\section{Effect of saline infusion}

With the exception of one serum sample (RIT 14), collected on the 2nd day after infusion of saline, all other titres determined in 5 sows were within the range of 10-12 (Text-fig. 1).

\section{Effect of seminal plasma on rosette formation}

Preincubation of lymphocytes in undiluted seminal plasma and in seminal plasma diluted 1 in 5 with HBSS caused an almost complete agglutination of cells. A slight clumping of lymphocytes was observed up to a seminal plasma dilution of 1 in 80 . Therefore the number of rosettes was only counted in dilutions of 1 in 10 to 1 in 5120. Seminal plasma induced a concentration dependent inhibition of spontaneous rosettes. The decrease of the rosette numbers was significant up to a dilution of 1 in 320. The results of this experiment are summarized in Table 1.

To investigate whether the absorption of seminal plasma from the uterus could be responsible for EPF-positive titres after intracervical infusion or mating with a vasectomized boar, seminal plasma was diluted with a non-pregnancy serum and the effect on rosette formation was evaluated. After inactivation and dialysis, a procedure routinely employed for all serum samples (Morton, Morton \& Ellendorff, 1983) significant differences between the seminal plasma dilutions and the control serum for the proportion of rosette-forming lymphocytes were no longer detectable (Table 2). With the control serum an RIT of 10 was determined in each of 3 repeated assays and the corresponding titres for the seminal plasma dilutions were of 14 and 18 for 1 in $80,12,14$ and 12 for 1 in 160,12,14 and 10 for 1 in 320 and 14 and 10 for 1 in 640. Twice (at a dilution of 1 in 80 and 1 in 
Table 1. Effect of preincubation of pig lymphocytes in different seminal plasma dilutions on the formation of spontaneous rosettes

\begin{tabular}{lcc}
\hline \multicolumn{1}{c}{ Preincubation in } & $\begin{array}{c}\text { Rosette forming } \\
\text { lymphocytes }(\%)\end{array}$ & $\begin{array}{c}\text { Rosette inhibition } \\
(\%)\end{array}$ \\
\hline HBSS & $10 \cdot 7 \pm 0.98$ & - \\
Seminal plasma dilutions & & \\
$1: 10$ & $0.6 \pm 0.21^{* *}$ & $94 \cdot 4$ \\
20 & $1 \cdot 3 \pm 0.39^{* *}$ & 87.9 \\
40 & $2 \cdot 7 \pm 0.51^{* *}$ & $74 \cdot 8$ \\
80 & $2 \cdot 2 \pm 0.43^{* *}$ & 79.4 \\
160 & $4 \cdot 8 \pm 0.84^{* *}$ & $55 \cdot 2$ \\
320 & $8.0 \pm 0.98^{*}$ & 25.2 \\
640 & $9 \cdot 0 \pm 0.57$ & 15.9 \\
1280 & $10.5 \pm 1.01$ & 1.9 \\
2560 & $10.5 \pm 0.93$ & 1.9 \\
5120 & $10.6 \pm 0.67$ & 0.9 \\
\hline
\end{tabular}

Experiments were done in triplicate. The values represent the data of 5 separate tests. The number of rosettes formed after preincubation of lymphocytes in HBSS was chosen as the control.

${ }^{*} P<0.05 ;{ }^{* *} P<0.001$ compared with controls.

Table 2. Effect of the addition of seminal plasma to a non-pregnancy serum of sows on the formation of rosettes

\begin{tabular}{|c|c|c|c|c|c|c|}
\hline \multirow{2}{*}{$\begin{array}{l}\text { Antilymphocyte } \\
\text { serum } \\
\text { dilution }\end{array}$} & \multirow[b]{2}{*}{ RIT } & \multirow{2}{*}{$\begin{array}{l}\text { Control } \\
\text { serum }\end{array}$} & \multicolumn{4}{|c|}{ Seminal plasma diluted in control serum } \\
\hline & & & $1: 80$ & $1: 160$ & $1: 320$ & $1: 640$ \\
\hline $\begin{array}{l}1: 10^{3} \\
1: 4 \times 10^{3} \\
1: 16 \times 10^{3} \\
1: 64 \times 10^{3} \\
1: 256 \times 10^{3} \\
1: 10^{6} \\
1: 4 \times 10^{6}\end{array}$ & $\begin{array}{l}10 \\
12 \\
14 \\
16 \\
18 \\
20 \\
22\end{array}$ & $\begin{array}{l}\frac{55 \cdot 1 \pm 2.45 * *}{92.6 \pm 5 \cdot 82} \\
96.8 \pm 12.08 \\
84.8 \pm 9.73 \\
97.2 \pm 11.80 \\
85.6 \pm 1 \cdot 31 \\
98.8 \pm 1.64\end{array}$ & $\begin{array}{l}35.4 \pm 1.36^{* * *} \\
76 \cdot 9 \pm 1 \cdot 30 \\
72 \cdot 3 \pm 2.92^{*} \\
69 \cdot 1 \pm 11 \cdot 19^{*} \\
74.7 \pm 14.37 \\
995.8 \pm 26.98 \\
79.3 \pm 10 \cdot 11\end{array}$ & $\begin{array}{l}45 \cdot 1 \pm 6.22^{* *} \\
73 \cdot 3 \pm 2 \cdot 30^{*} \\
74 \cdot 0 \pm 8.14 \\
89.5 \pm 5 \cdot 00 \\
91 \cdot 5 \pm 12 \cdot 62 \\
86 \cdot 0 \pm 9 \cdot 61 \\
88.5 \pm 6.65\end{array}$ & $\begin{array}{l}51 \cdot 1 \pm 3.90^{* *} \\
80 \cdot 1 \pm 14.91 \\
74.3 \pm 5.84 \\
81 \cdot 8 \pm 4.93 \\
88.7 \pm 8.75 \\
92 \cdot 0 \pm 7.65 \\
88.5 \pm 4.00\end{array}$ & $\begin{array}{l}37.5 \pm 3.58^{*} \\
71 \cdot 2 \pm 9.90 \\
75 \cdot 3 \pm 4 \cdot 19 \\
79.4 \pm 5.30 \\
79.4 \pm 4 \cdot 18 \\
75.6 \pm 3.97 \\
85.1 \pm 6.88\end{array}$ \\
\hline $\begin{array}{l}\text { Control (HBSS) } \\
\text { Relative }(\%) \\
\text { Absolute }(\%)\end{array}$ & & $\begin{array}{c}100 \\
10 \cdot 2 \pm 0.92\end{array}$ & $\begin{array}{c}100 \\
11 \cdot 1 \pm 1 \cdot 08\end{array}$ & $\begin{array}{c}100 \\
11 \cdot 5 \pm 1 \cdot 23\end{array}$ & $\begin{array}{c}100 \\
9 \cdot 4 \pm 1 \cdot 40\end{array}$ & $\begin{array}{c}100 \\
10 \cdot 4 \pm 2 \cdot 11\end{array}$ \\
\hline
\end{tabular}

Values represent mean rosette numbers \pm s.e.m. (as \% of the internal control without antilymphocyte serum) of 3 separate assays.

Lymphocytes were preincubated in the serum of a non-pregnant pig before and after the addition of seminal plasma at different dilutions. The underlined values mark the highest dilution of the antilymphocyte serum which induced at least a $25 \%$ inhibition of rosette formation.

* $P<0.05,{ }^{* *} P<0.02,{ }^{* * *} P<0.002$ compared to the control without antilymphocyte serum.

$640)$ no clear end-point of the titration could be established. The mean rosette numbers $(\%$ of the internal control without antilymphocyte serum) of the three repeated tests are shown in Table 2. A statistically significant response was detectable up to a seminal plasma dilution of 1 in 160 .

\section{Discussion}

In contrast to a study by Morton et al. (1976) which did not detect any change in the rosette inhibition titres after copulation of oestrous mice with a vasectomized male, our experiments, 
under comparable conditions, revealed EPF activity in the serum of most of the sows. However, with the exception of a single animal, which showed elevated titres for $72 \mathrm{~h}$, all other animals returned to the normal range within $48 \mathrm{~h}$ after mating. A similar but statistically not significant temporary increase of serum inhibition titre occurred in 3 out of 5 pigs after the intracervical infusion of seminal plasma. An enhanced rosette inhibition was also detected in 2 pigs before any treatment and in one sow $24 \mathrm{~h}$ after sham copulation and one sow $48 \mathrm{~h}$ after infusion of saline. Since our test system consistently produced a rate of about $9 \%$ false-positive results (Koch $\&$ Ellendorff, 1985), it appears most probable that the increase of the mean rosette inhibition titre after mating with a vasectomized boar is primarily due to the presence of seminal plasma within the female genital tract, and is neither induced by mechanical stimulation of mating nor the infusion of a particular fluid volume into the uterus.

The mechanisms responsible for this induction of EPF activity are not known. Mouse zygotes have been reported to release a hypothetical ovum factor, which subsequently stimulates the production of EPF (Cavanagh et al., 1982). The release of this ovum factor could also be triggered by incubation of ova in calcium- and magnesium-free culture medium or medium containing hyaluronidase. Both of these conditions are known to activate mouse ova parthenogenetically (Kaufman, 1978). Although hyaluronidase is not present in seminal plasma of vasectomized males (Polakoski, Syner \& Zaneveld, 1976), it is possible that other constituents induce a similar effect, and the rapid decrease of elevated serum inhibition titres beyond $24 \mathrm{~h}$ might be explained by the failure of temporarily activated ova to develop further.

If the body weight and the ejaculate volume of the pig $(150 \mathrm{~kg}, 150 \mathrm{ml})$ and the mouse $(30 \mathrm{~g}$, $0.003 \mathrm{ml}$; Snyder, 1966) are compared, the boar produces at least a 10 -fold larger ejaculate volume than does the mouse. Such a large seminal plasma volume would increase the chance of exposure of the eggs to the possible triggering component and would explain why EPF activity after mating with a vasectomized male has so far only been detected in the pig. It is known that the majority of the seminal fluid disappears within $2 \mathrm{~h}$ after mating in the pig (Hunter, 1975). Although there is a temporary obstruction of the cervix by bulbourethral gland secretions, the largest part of the ejaculate will certainly be lost by reflux through the vulva. However, a partial resorption of seminal plasma constituents cannot be excluded. The effects observed after addition of seminal plasma to a non-pregnant serum indicate that this mechanism might be involved in the increase of serum rosette inhibition titres after mating with a vasectomized boar.

If it is accepted that the inhibition of spontaneous rosettes reflects an immunosuppression (Bach, Dardenne \& Fournier, 1969) then our data demonstrate a strong inhibitory activity of pig seminal plasma. Immunosuppressive properties of human, bovine and murine seminal plasma have been described for a number of in-vitro tests. These include the depression of lymphocyte stimulation by mitogens (Stites \& Erickson, 1975; Prakash, Coutinho \& Möller, 1976; Pitout \& Jordaan, 1976; Lord, Sensabaugh \& Stites, 1977; Marcus, Freisheim, Houk, Herman \& Hess, 1978; Marcus, Hess, Herman, Troiano \& Freisheim, 1979; Anderson \& Tarter, 1982), natural antigens (Lord et al., 1977) and allogeneic cells (Stites \& Erickson, 1975; Levis, Whalen \& Sherins, 1976; Prakash et al., 1976; Lord et al., 1977) as well as the inhibition of E-rosette formation (Marcus et al., 1979).

Studies on the characterization of the component(s) responsible for the immunosuppressive effect of seminal plasma are conflicting. In human and bovine seminal plasma activity was detected in high molecular weight fractions $(>100000)$ as well as in fractions with a much lower molecular weight (<14000) (Prakash et al., 1976; Pitout \& Jordaan, 1976; Lord et al., 1977). The wide molecular weight range and the magnitude of immune response suppression indicate the involvement of more than one factor (Anderson \& Tarter, 1982). This presumption is supported by our experiments. Inactivation and dialysis obviously remove the inherent rosette-inhibiting activity of seminal plasma. However, as seminal plasma still augments the effect of antilymphocyte serum, there are apparently at least two different components present, one of which could be EPF or an EPF-like substance. Prostaglandins are only one group of possible candidates responsible for 
the inherent inhibitory activity of seminal plasma (Stites \& Erickson, 1975). Moreover, the polyamines spermine and spermidine are converted into active inhibitors of lymphocyte proliferation by a polyamine oxidase (Morgan \& Illei, 1980), also present in seminal plasma (Polakoski et al., 1976).

Whether the detection of EPF activity after mating of oestrous pigs with a vasectomized boar is caused by a non-specific activation of ova or depends on the resorption of immunosuppressive factors included in seminal plasma has to be clarified by further investigation. The detection of EPF-like activity in serum of patients with testicular germ-cell tumours has already shown that this phenomenon is not limited to females (Rolfe, Morton, Cavanagh \& Gardiner, 1983). Since in humans many pregnancy-associated proteins are detected not only in sera of tumour patients but also in seminal plasma (Chard, 1982), the question arises whether EPF is now another member of the increasing number of onco-developmental proteins (Whyte \& Heap, 1983).

We thank Mrs I. Stelter for excellent technical assistance. This work was supported by the Deutsche Forschungsgemeinschaft.

\section{References}

Anderson, D.J. \& Tarter, T.H. (1982) Immunosuppressive effects of mouse seminal plasma components in vivo and in vitro. J. Immunol. 128, 535-539.

Bach, J.F., Dardenne, M. \& Fournier, C. (1969) In vitro evaluation of immunosuppressive drugs. Nature, Lond. 222, 998-999.

Cavanagh, A.C., Morton, H., Rolfe, B.E. \& Gidley-Baird, A.A. (1982) Ovum factor: a first signal of pregnancy? Am. J. Reprod. Immunol. 2, 97-101.

Chard, T. (1982) Proteins of the human placenta: Some general concepts. In Pregnancy Proteins, pp. 3-21. Eds J. G. Grudzinskas, B. Teisner \& M. Seppälä. Academic Press, Sydney.

Hunter, R.H.F. (1975) Physiological aspects of sperm transport in the domestic pig, sus scrofa. II. Regulation, survival and fate of cells. Br. vet. J. 131, 681690.

Hunter, R.H.F. \& Dziuk, P.J. (1968) Sperm penetration of pig eggs in relation to the timing of ovulation and insemination. J. Reprod. Fert. 15, 199-208.

Kaufman, M.H. (1978) The experimental production of mammalian parthenogenetic embryos. In Methods in Mammalian Reproduction, pp. 21-47. Ed. J. C. Daniel, Jr. Academic Press, New York.

Koch, E. \& Ellendorfi, F. (1985) Prospects and limitations of the rosette inhibition test to detect activity of early pregnancy factor in the pig. J. Reprod. Fert. 74, 2938.

Koch, E., Morton, H., Morton, D. \& Ellendorff, F. (1982) Früher Trächtigkeitsfaktor (EPF) beim Schwein. In Physiologie und Pathologie der Fortpflanzung. Verhandlungsbericht 7. Veterinär-Humanmedizinische Tagung, Giessen, pp. 168-170. Eds K. Semm, H. Tillmann, W. Gehring \& L. Mettler. Alete Informationsdienst, Munich.

Levis, W.R., Whalen, J.J. \& Sherins, R.J. (1976) Mixed cultures of sperm and leucocytes as a measure of histocompatibility in man. Science N.Y. 191, 302304.

Lord, E.M., Sensabaugh, G.F. \& Stites, D.P. (1977) Immunosuppressive activity of human seminal plasma. I. Inhibition of in vitro lymphocyte activation. $J$. Immunol. 118, 1704-1711.
Marcus, Z.H., Freisheim, J.H., Houk, J.L., Herman, J.H. \& Hess, E.V. (1978) In vitro studies in reproductive immunology. 1. Suppression of cellmediated immune response by human spermatozoa and fractions isolated from human seminal plasma. Clin. Immunol. Immunopath. 9, 318-326.

Marcus, Z.H., Hess, E.V., Herman, J.H., Troiano, P. \& Freisheim, J. (1979) In vitro studies in reproductive immunology. 2. Demonstration of the inhibitory effect of male genital tract constituents on PHAstimulated mitogenesis and E-rosette formation of human lymphocytes. J. Reprod. Immunol. 1, 97107.

Morgan, D.M.L. \& Illei, G. (1980) Polyamine-polyamine oxidase interaction: part of maternal protective mechanism against fetal rejection. Br. med. J. 280, 1295-1297.

Morton, H., Hegh, V. \& Clunie, G.J.A. (1976) Studies of the rosette inhibition test in pregnant mice: Evidence of immunosuppression? Proc. R. Soc. Lond. B 193, 413-419.

Morton, H., Nancarrow, C.D., Scaramuzzi, R.J., Evison, B.M. \& Clunie, G.J.A. (1979) Detection of early pregnancy in sheep by the rosette inhibition test. $J$. Reprod. Fert. 56, 75-80.

Morton, H., Rolfe, B.E., McNeill, L., Clarke, P., Clarke, F.M. \& Clunie, G.J.A. (1980) Early pregnancy factor: tissues involved in its production in the mouse. $J$. Reprod. Immunol. 2, 73-82.

Morton, H., Rolfe, B. \& Cavanagh, A. (1982a) Early pregnancy factor: Biology and clinical significance. In Pregnancy Proteins, pp. 391-405. Eds J. G. Grudzinskas, B. Teisner \& M. Seppälä. Academic Press, Sydney.

Morton, H., Tinneberg, H.R., Rolfe, B., Wolf, M. \& Mettler, L. (1982b) Rosette inhibition test: a multicentre investigation of early pregnancy factor in humans. J. Reprod. Immunol. 4, 251-261.

Morton, H., Morton, D.J. \& Ellendorff, F. (1983) The appearance and characteristics of early pregnancy factor in the pig. J. Reprod. Fert. 68, 437-446.

Nancarrow, C.D., Evison, B.M., Scaramuzzi, R.J. \& Turnbull, K.E. (1979) Detection of induced death of 
embryos in sheep by the rosette inhibition test. $J$. Reprod. Fert. 57, 385-389.

Pitout, M.J. \& Jordaan, J.H. (1976) Partial purification of an antimitogenic factor from human semen. $I n t . J$. Biochem. 7, 149-151.

Polakoski, K.L., Syner, F.N. \& Zaneveld, L.J.D. (1976) Biochemistry of human seminal plasma. In Human Semen and Fertility Regulation in Man, pp. 133-143. Ed. E. S. E. Hafez. C.V. Mosby Company, St. Louis.

Prakash, C., Coutinho, A. \& Möller, G. (1976) Inhibition of in vitro immune responses by a fraction from seminal plasma. Scand. J. Immunol. 5, 77-85.

Rolfe, B.E., Morton, H., Cavanagh, A.C. \& Gardiner, R.A. (1983) Detection of an early pregnancy factorlike substance in sera of patients with testicular germ cell tumors. Am. J. Reprod. Immunol. 3, 97-100.
Smart, Y.C., Roberts, T.K., Fraser, I.S., Cripps, A.W. \& Clancy, R.L. (1982) Validation of the rosette inhibition test for the detection of early pregnancy in women. Fert. Steril. 37, 779-785.

Smidt, D. (1965) Die Schweinebesamung, Verlag H. \& M. Schaper, Hannover.

Snyder, R.L. (1966) Collection of mouse semen by electroejaculation. Anat. Rec. 155, 11-14.

Stites, D.P. Erickson, R.P. (1975) Suppressive effect of seminal plasma on lymphocyte activation. Nature, Lond. 253, 727-729.

Whyte, A. \& Heap, R.B. (1983) Early pregnancy factor. Nature, Lond. 304, 121-122.

Received 15 June 1984 